\title{
The Problems of Managing Tourism Business in Bangladesh: Causes and Remedial Measures
}

\section{Ferdouse Ara Tuli}

Senior Lecturer, Faculty of Business, ASA University Bangladesh, BANGLADESH

\begin{abstract}
Tourism Business is one of the fastest growing businesses in Bangladesh. It creates ample job opportunities for the unemployed people in Bangladesh. This business has been contributing remarkable to boost-up the economic development in Bangladesh. But the tourism business in Bangladesh has been suffering from the problems of effective management. Thus, this article aims to explore the causes of management problems facing the tourism business in Bangladesh. This article also attempts to provide the remedial measures to overcoming the existing management problems facing the tourism business in Bangladesh.
\end{abstract}

Keywords: Tourism, Business, Employment, Management, Bangladesh JEL Classification Code: M 10; M 12; M 14

\section{INTRODUCTION}

Bangladesh is a developing country. It is located in the Indian Sub-Continent. The present population of Bangladesh is approximately 16 crore and unemployment rate is 14.2 percent. The various education institutions of Bangladesh are producing thousand-thousand graduates in every year. But these graduates do not get their jobs from the existing job facilities in Bangladesh. Thus, the government and private authorities can take the initiatives to flourish the tourism industry in this country. Many unemployed people may start their career in this industry when it will be developed. As a result, the unemployment rate of this country will be decreasing gradually.

In the modern business world, tourism has been considering as the world's largest and rapid growing industry. It is the most emerging industry in Bangladesh. It contributes tremendously to the economic development of Bangladesh.

Bangladesh is a country with full natural beauty. The reasons it behind some parts of Bangladesh are covered by Hills and some other parts by the rivers. It has six sea beaches of which one is the longest sea beach of the world. The largest Mangrove Forest Sundarban is located at the south part of Bangladesh and it enhances the opportunity of bringing more tourists in Bangladesh. Besides, there are many archaeological sites which can swiftly attract 
local and foreign tourists. Tourists are ready to pay more for visiting these places. But there are some problems of developing and making this industry more lucrative to the tourists. Tourism sector would be one of the potential sectors to earn huge foreign currency and contribute the economy of Bangladesh if proper policies and strategies can be formulated and implemented by the government in this country. For attracting more local and foreign tourists, natural beauty should be protected and facilities should be increased in Bangladesh immediately.

\section{Objectives of the Study}

The study has been conducted with the following objectives:

- To investigate the various problems relating to managing the tourism business in Bangladesh

- To explore the causes of the problems relating to managing the tourism business in Bangladesh

- To provide some remedial measures to overcoming the problems relating to managing the tourism business in Bangladesh

\section{Limitations of the Study}

The main limitation of the study is that the author has not used structured questionnaire to collect the relevant data/information from the primary sources. Despite this limitation, the author has tried to accurately find out the root causes of the problems of managing tourism business in Bangladesh and also to provide some possible remedial measures to overcoming these problems which make the business more successful in Bangladesh.

\section{Methodology OF THE Study}

The methodology for the study has been designed in the following ways:

- Data Sources: There are two sources of data. These are as follows:
$\checkmark$ Primary data
$\checkmark$ Secondary data

- Data Collection Methods: The primary data has been collected from the following ways:

$\checkmark$ Face-to-face discussion

$\checkmark$ Focused group discussion

$\checkmark \quad$ Informal meeting

$\checkmark$ Small round-table discussion

The secondary data has been collected from the following sources:

$\checkmark$ Published relevant books, newspapers and magazines

$\checkmark$ Published relevant journals and articles

$\checkmark \quad$ Website of Bangladesh Parjatan Corporation

$\checkmark$ Website of Bangladesh Bureau of Statistics

$\checkmark$ Website of Bangladesh Bank

$\checkmark$ Website of Bangladesh Bureau of Research

$\checkmark \quad$ Website of Ministry of Cultural Affairs

- Data Analysis Technique: The present study is descriptive in nature. So, the author has used Microsoft Office Package ${ }^{\circledR}$ to analyze the data in this study.

\section{LITERATURE REVIEW}

Tourism has already been emerged as vital industry in Bangladesh. This industry can provide job facilities to the unemployed people in Bangladesh and also can contribute to the economic development in this country. Ali and Mohsin (2008) pointed out that tourism is considered as rapid growing industry not only in Bangladesh but also all-over the world. It is 
one of the leading sources of foreign currency in Bangladesh. But this sector is now facing severe problems. Parveen (2013) mentioned that the tourism industry in Bangladesh is now suffering from the instrumental facilities, which may discourage tourists to visit the historical places in Bangladesh. Alauddin, shah, and Ullah (2014) pointed out that the problems of developing tourism industry in Bangladesh. According to them, the tourism industry in Bangladesh in now suffering from the problems such as accommodation, poor image, transportation, lack of proper facility, complicated visa and travel facilities, lack of initiative to preserve , conserve maintain the tangible tourism products, lack of security, unstable political situation, lack of required fund allocation in national budget, lack of international standard hotel etc. Hall and Page (2000) told that the major problems of tourism in Bangladesh are natural disasters, unemployment, overpopulation and economic underdevelopment.

From the above literature, it can be said that there are many problems facing the tourism industry in Bangladesh. Thus, the authority of the tourism industry in Bangladesh is keeping busy them for managing the various problems to smoothly conduct the activities in this sector of Bangladesh. For this reason, the author has selected this topic to conduct the present study.

\section{TOURISM BUSINESS IN BANGLADESH}

Tourism business is becoming popular in Bangladesh day-by-day. The reason behind is the necessity of the people in Bangladesh. Some people are involved with conducting the tourism business and some people are availing the facilities of the business. This business provides tremendous job facilities to unemployed people. It contributes regularly to boost up the economy of Bangladesh. It also provides pleasure to the tourists. The tourism business in Bangladesh has been explained in the following ways:

\section{Definition of Tourism}

There is no universal definition of tourism. In still now, different people have defined the term tourism in different ways based on their own justification. According to Wikipedia( http:// em.wikipedia.org/wiki/tourism), tourism means going out and visiting place for religious purpose, gathering knowledge and having pleasure, fun, or economic benefit. Tourism is travel for recreational, leisure, or business purposes.

The word 'tourism' definition is not static in still today. There is no reliable available definition of tourism. According to the definition of UNWTO, "Tourism comprises the activities of persons traveling to and staying in places outside their usual environment for not more than one consecutive year for leisure, business and other purposes". According to the International Ecotourism Society ( www.ecodirectory.com), " Responsible travel to natural areas that conserve the environment and improves the well-being of local people". Methieson and Wall (1982) has defined the term 'Tourism'. According to them, "Tourism is the movement of people to destination outside their normal places of work and residence, the activities undertaken during their study in those destinations, and the facilities created to cater to their needs".

\section{Types of Tourism in Bangladesh}

There are various types of tourism in Bangladesh. These are as follows:

i) Education Tourism

ii) Medical Tourism

iii) Business Tourism

iv) Office Tourism

v) Site Tourism

vi) Religious Tourism

vii) Other Tourism 
i) Education Tourism: Foreign tourists come in Bangladesh for education purpose. Many govt. and private universities in Bangladesh are regularly arranging international seminars, conferences, and symposiums. They are inviting foreigners to attend in these programs. These activities are increasing day-by-day for meeting the demand of the current world. As a result, the number of foreign tourists is increasing gradually in the education sector of Bangladesh.

ii) Medical Tourism: There are some international standard hospitals in Bangladesh at present. Many foreign tourists come in Bangladesh to accomplish various medical activities. At present, the medical tourism is not well recognized in Bangladesh. But it may create a great opportunity in near future.

iii) Business Tourism: A large number of people across the world come in Bangladesh for business purpose. Bangladesh is a good for conducting business activities because of cheap labor cost.

iv) Office Tourism: At present, there are so many multinational, international and goal companies operating their business activities in Bangladesh. In order to accomplish official activities, many high officials and delegates come to Bangladesh in every year.

v) Site Tourism: Basically, foreign tourists come in Bangladesh for visiting in natural places for their enjoyment. Beside, many local tourists visit the natural placers of Bangladesh for their recreation.

vii) Other Tourism: The followings include into the other tourism:

- $\quad$ Bicycle touring

- Boat sharing

- Cultural tourism

- Dark tourism

- Rural tourism

- $\quad$ River tourism

- Nautical tourism

- Jihadi tourism

- Sports tourism

- Ritual tour

- Walking tourism

- Wildlife tourism

- Water tourism

\section{Tourism Products in Bangladesh}

There are three World Heritage sites in Bangladesh, such as Mahasthangarh, Mosque city of Bagerhat and the Sundarban. These attract huge number of tourists in Bangladesh. The longest sandy beach is situated at Cox's Bazar in Bangladesh. Besides, Patenga, Parki, Teknaf, St. Martin Island and Kuakata Sea beach are definitely quenching the thirst of local and foreign tourists. The largest mangrove forest is situated in Bangladesh. It beauty may amaze anyone while traveling in steam boats and enjoying the diversity and ecosystem of the forest.

The private and government authorities of Bangladesh are now trying to construct the world class hotels, resorts, motels for the tourists. As a result, local and foreign tourists come to the historical places of Bangladesh for their enjoyment.

Tourists both local and foreign may come to see the lake district of Rangamati, the lake town of Kaptai, the hilltop town of Khagrachhari and the roof of Bangladesh Bandarban. They can come to close the nature of beauty in these places of Bangladesh. The tourists can develop their archeological knowledge about South Asia and Bangladesh from visiting the archeological sites of Buddhists monasteries, Hindu temples and Muslim mosques and 
places, etc. In addition to these, there are various nice places and institutions of Bangladesh which might draw the attractions of the tourists.

Income of Tourism and Travels in Bangladesh

The incomes of tourism and travels in Bangladesh are shown in the following table:

Table-1: Income of Tourism and Travels in Bangladesh

\begin{tabular}{|c|c|c|}
\hline SL & YEAR & AMOUNT ( LAKH TK.) \\
\hline 1. & $2010-2011$ & 2380.68 \\
\hline 2. & $2011-2012$ & 3251.03 \\
\hline 3. & $2012-2013$ & 3161.12 \\
\hline
\end{tabular}

Source: Bangladesh Bank and BPC Web Page, available from: http:// www.bangladeshtourism.gov.bd

The above table shows the income of tourism and travels in Bangladesh respectively in the year 2010 -2011, 2011-2012 and 2012- 2013. The income of tourism and travels in Bangladesh in the 2010-2011 is Tk. 2380.68 lakh, 2011-2012 is Tk. 3251.03 lakh and 2012-2013 is Tk. 3161.12 lakh. These statistics indicate that the income of tourism and travels in Bangladesh in the year 2011-2012 is higher than the year 2010-2011. But the income in the year 2012-2013 is lower than the year 2011-2012 income. The income trend is in decline. The income of tourism and travels in Bangladesh can be presented in the graph. The graph is as follows:

Figure-1: Income of Tourism and Travels in Bangladesh

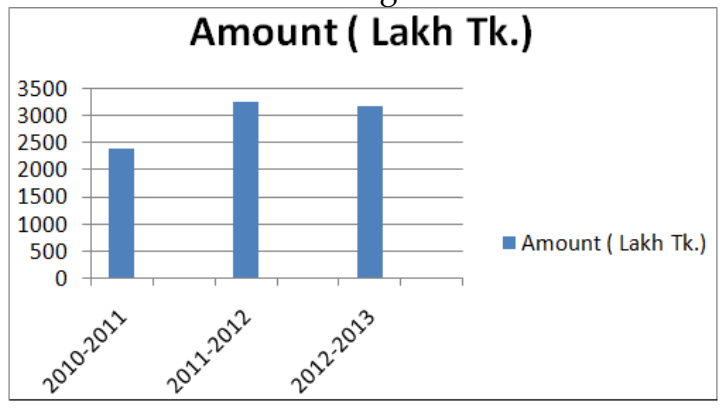

Source: Author's own calculation

The above table shows the income of tourism and travels in Bangladesh. The income of tourism and travels in Bangladesh is not gradually up warding. Thus, the authority should be taken some necessary measures for ensuring the continuous upward growth \& development.

\section{Development of Tourism Sector in Bangladesh}

The most dynamic and growing and also the most lucrative sector throughout the world is tourism industry. In order to increase the share in the world tourism market, each and every country is trying with the overall changing of the country. If a country wants enhance the tourism industry, then the authority of the country needs to be taken urgent innovative and strategic measures. The following steps are badly needed to develop and provide the tourism industry in Bangladesh at present:

i) To make strengthen Bangladesh Parjatan Corporation: The only national tourist organization in Bangladesh is Bangladesh Parjatan Corporation. Thery should be given sufficient autonomy and power to take timely decision on issues relating to diversification of business, strategic joint venture with local and foreign partners, and ensure the required organizational development. 
ii) To provide effective training to the employees: The staffs of hotels, motels and restaurants need training. In this regard, BPC should provide training to these people so that they can give standard service to the tourists.

iii) To formulate adequate rules \& regulations: The government of Bangladesh should be formulated adequate rules \& regulations for developing and maintaining the tourism industry in Bangladesh. The government of Bangladesh should also modify the existing tourism rules \& regulations and make it up-to-date.

iv) To give sufficient advertisement: The public and private owners of tourism organizations in Bangladesh should give adequate advertisement in the electronic and print media within and outside the country regarding different tourist sports and facilities. They can also make brochures, booklet, leaflets, diary, calendar, pen, etc. for the tourists.

v) To develop the infrastructure: The infrastructure is one of the essential things to develop the tourism industry in Bangladesh. In this case, the government of Bangladesh should develop the roads \& highways, water, electricity, gas and accommodation facilities for the tourists. The proper development of infrastructure may enhance the number of both local and foreign tourists in Bangladesh.

vi) To create sub-regional zones: Tourists want to get quick service. Thus, the government and private owners may establish the sub-regional zones so that the tourists can easily get service. It may be helpful to attract a large number of local and foreign tourists in Bangladesh.

\section{Findings AND ANALYSIS OF THE STUDY}

Tourism business is one of the lucrative and timely businesses at present in Bangladesh. It provides job opportunities for the unemployed people in this country. It also provides valuable contribution to the economic development in Bangladesh. But the various factors are affecting the image of tourism in Bangladesh at present. This industry is now suffering from plenty of problems. These are as follows:

- The culture of Bangladesh is not favorable for the foreign tourists. That is why, the foreign tourists do not want to come in Bangladesh for their enjoyment.

- The tourism industry of Bangladesh is now suffering from the problems of trained, skilled and efficient manpower.

- The proper publicity is essential for the development of tourism industry in Bangladesh. But this industry is now suffering from the problem of proper and adequate advertisement.

- The tourism industry of Bangladesh needs adequate budgetary allocation in the national budget. But the government of Bangladesh doe not allocate sufficient budget for the development of this industry.

- The sound political environment is badly needed for the development of tourism industry in Bangladesh. But the political environment of Bangladesh is not stable due to personal interest of the political parties.

- The positive circular is essential for the development of tourism industry in Bangladesh. But Bangladesh is highlighted in foreign electronic and print media as a country of cyclone, strike, flood, different types of violence, etc.

- The good law and order situation is essential for the development of tourism in a country. But terrorism and robbing are common incident in this sector of Bangladesh. As a result, tourists' specifically foreign tourists may not want to come in Bangladesh.

- The easy and simple formalities are essential for the tourists so that they can easily collect visa from Bangladesh Mission located in different countries in the world. But the visa and travel formalities in Bangladesh Mission are so much complicated. For this reason, foreign tourists do not want to come in Bangladesh for their enjoyment. 
- The tourists need standard infrastructure facilities. But the present infrastructure facilities of Bangladesh are not attracting the foreign tourists.

- The strong instrumental supports are needed for the development of tourism in a country. But the Ministry of Civil Aviation and Tourism in general and the BPC in particular are suffering from the problems of instrume3ntal capacity.

- The tangible tourism products need to maintain properly for attracting the tourists for long-long time in Bangladesh. In this case, the authority is not active to preserve, conserve and maintain the tangible tourism products. As a result, the tourists may not feel comfortable to come in Bangladesh.

\section{RECOMMENDATIONS}

The tourism industry in Bangladesh is now facing some severe problems. The following suggestions are recommended to overcoming these problems for ensuring the stable development of tourism industry in Bangladesh:

- A favorable culture should create for the foreign tourists so that they are feeling comfortable to come in Bangladesh for their enjoyment.

- The public and private authority should establish the different training and education institutes to produce trained, skilled, and efficient manpower for the tourism industry in Bangladesh so that they can provide quick service with quality to the tourists.

- The proper and adequate advertisement should be given by the respective authority in various national and international electronic and print media so that local and foreign tourists may get proper information about the overall tourism industry in Bangladesh.

- The government of Bangladesh should keep sufficient budgetary allocation in the national budget for the development of tourism industry in Bangladesh.

- A favorable political culture should be developed by the government of Bangladesh in consultation with all stakeholders for the greater interest of the country.

- The government of Bangladesh should take the immediate step to stop the negative news published in different foreign electronic and print media about the tourism industry in Bangladesh.

- The government of Bangladesh must come forward quickly to make sound law and order situation for the tourists so that the tourists may feel encourage to come to visit the various beautifully places in Bangladesh.

- The easy and simple visa \& travel formalities should be formulated immediately by the government of Bangladesh and send it to the Bangladesh Mission located in different countries all over the world.

- The government of Bangladesh should quickly take action for developing the infrastructure facilities of the country so that tourists may feel more excitement in their mind for coming in Bangladesh.

- The government of Bangladesh should quickly take the action for making stronger the Ministry of Civil Aviation and Tourism and BPC so that they must be more active to enhance the facilities for the tourists.

- The respective authority of Bangladesh should take immediate action for maintaining tangible tourism products of Bangladesh. As a result, the tourists can see these products for long time and can develop their knowledge. 


\section{CONCLUSION}

Bangladesh is one of the least developed countries in the world. Tourism has been considering as one of the fundamental pillars of economic development in every least developed country in the world. There are ample tourism resources in Bangladesh. Beside, the people of Bangladesh are very much simple and friendly. They like to care the foreign tourists with more hospitality. So, tourism sector of Bangladesh can earn huge amount of money from the tourists both local and foreign tourists. Thus, the government of Bangladesh should pay necessary attention to develop this sector by preparing and implementing effective strategic plans for the development of tourism sector in this country.

\section{REFERENCES}

Aktar S, Islam MS and Hossen SM. 2012. Human Resource Management Practices and Firms Performance in Bangladesh: An Empirical Study on Pharmaceutical Industry Asian Business Review, 1, 121-125.

Alam, Kazi, Wahidul (2002), "Bangladesh Tourism and the Dhaka Mart: 2002", The Bangladesh Observer, February 1, P. 6.

Alauddin, Md. Shah, Md. Gaffar, Hossain and Ullah, Habib (2014), "Tourism in Bangladesh: A Prospects Analysis", Information and Knowledge Management, Vol. 4, No. 5.

Ali, Mohammad, Mahboob and Mohsin, Chowdhury, Sefat-e ( 2008), " Different aspects of Tourism marketing strategies with special reference to Bangladesh: An Analysis", Business Review, A Journal of Business Administration, Khulna University, Vol. 6, No. 1 \& 2, January-December.

Charumbira LT. 2014. Strategic Management in Zimbabwean Profit and Non-profit Organizations: Identifying the Missing Tools in the Strategy Implementation Kit Bag Asian Business Review, 4, 7-13.

Das, Rajib, Kanti and Chakraborty, Jaba (2012), "An Evaluation Study on Tourism in Bangladesh", Developing Countries Studies, Vol. 2, No. 1.

Hall, C.M. and Page, S. (2000), "Tourism in South and Southeast Asia: Issues and Cases", London, Butterworth Heinemann, P. 2018.

Hossain, Md. Afjal, Khan, Md. Mizanur Rahman and Hasan, Md. Morshed (2005), "Potentials of Tourism Development in Bangladesh: An Empirical Study", Journal of Business Studies, Dhaka University, Vol. XXVI, No. 1 , June.

Mohaimen MA. 2013. Talent Management: Three new Perceptions intended for managing and retaining Talent in Bangladesh Asian Business Review, 3, 7-15.

Parveen, Dr. Jannat, Ara (2013), “ Current Status of Tourism Industry In Bangladesh: An Empirical Evaluation", Scientific Research Journal ( SCIRJ), Vol. 1, Issue 1, August.

Sabur MA. 2013. Total Quality Management as a Tool for Decision Making Asian Business Review, 3, 121-125.

Shafi, Mahmuda (1985), "Tourism Marketing: Pros and cons", Tourism Recreation Research, Vol. X, No. 1, Lucknow, India.

Sultana, M. (2014). Ethics in Teaching Profession. ABC Journal of Advanced Research, 3(1), 44. doi:10.15590/abcjar/2014/v3i1/53475

Talukder, Abu, Sayeed (1984), "Development of tourism in Bangladesh: need for consumer motivation ," The Dhaka University Studies, Part-C, 5 (1), ( P. 83-97).

Tinne WS. 2013. Nation Branding: Beautiful Bangladesh Asian Business Review, 2, 31-36.

Uddin, Mohammad, Asraf and Ahmed, Shaheen (2005), “Tourism in Bangladesh: Present status, Problems and Prospects," Journal of Business Studies, Southeast University, Vol.1 No. 2, July, P. 143-154.

Website of Bangladesh Bank: www.bangladeshbank.org.bd

Website of Bangladesh Bureau of Research

Website of Bangladesh Bureau of Statistics

Website of Bangladesh Parjatan Corporation: http://www.parjatan.gov.bd/tourism

Website of Ministry of Civil Aviation 